Historic, Archive Document

Do not assume content reflects current scientific knowledge, policies, or practices. 

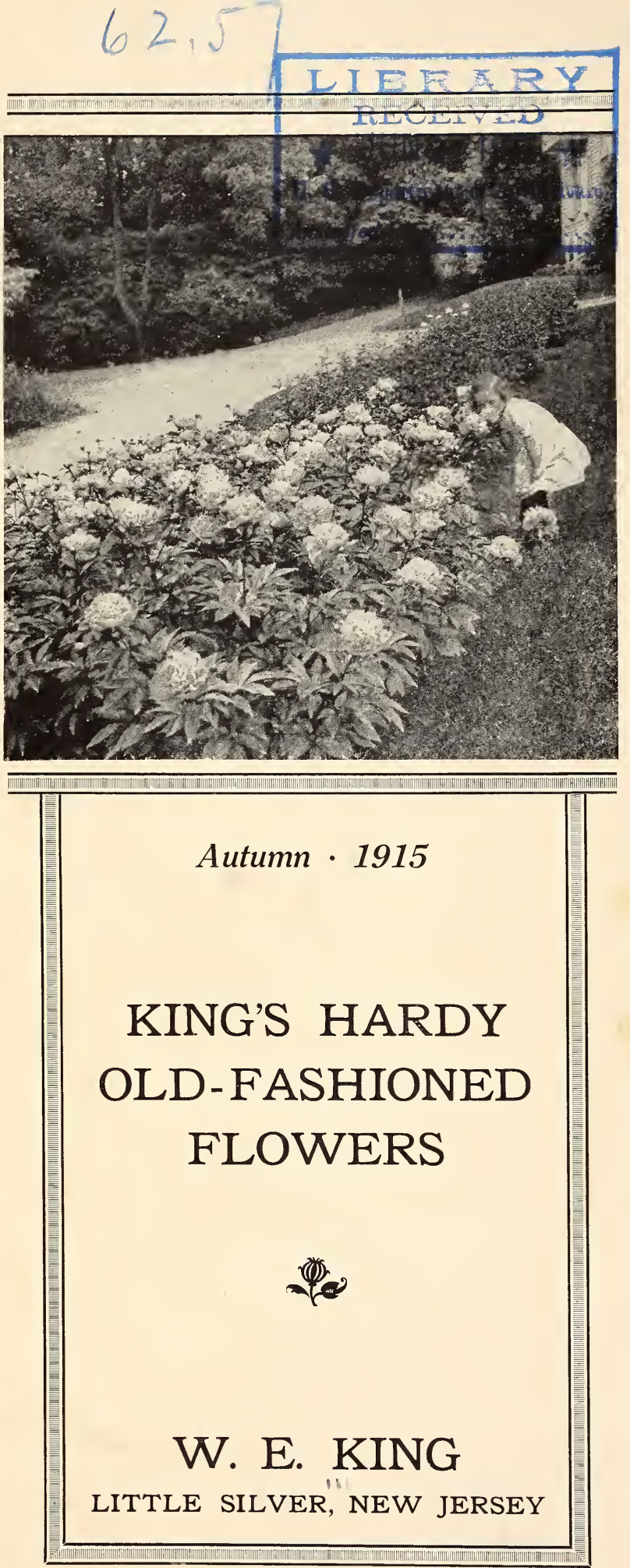


\section{Directions to Customers}

PLEASE READ

Place Your Order Early. It is advisable that you place your order early, even though you do not want the plants at once. State the time you want the plants shipped, and your order will be filled at that time with selected plants.

My Guarantee. I guarantee that you will be entirely satisfied with the plants and bulbs from here, or you can return them at once, and your money will be promptly refunded. A satisfied customer is my best advertisement.

Terms. Are strictly cash with order. If stock is to be reserved, I ask at least 25 per cent of amount with the order and the balance before shipment.

C. O. D. Shipments will be made only when 25 per cent of the amount of the order is sent with it. It is to your advantage, however, to pay cash in advance, as you save on the return charges.

Packing. No charge is made for boxes or packing, or delivery to express office or freight depot.

Parcel-Post Shipments. For my customers who live at a distance from the express office, I shall be pleased to forward by parcel post such plants as can be sent in that way, at the following additional cost: To all points east of the Mississippi River, Io per cent extra; to all points west of the Mississippi River, 20 per cent extra.

Express Shipments are advised, as this method is quicker, safer and cheaper except on very small packages.

Name and Address. Please write very carefully and as distinctly as possible, giving all necessary information so that prompt deliveries can be made. Ladies will kindly write the prefix, Miss or Mrs. before the name.

I Do Not Warrant in any way, expressed or implied, the description, quality or productiveness of any plants or bulbs I send out, and will not in any way be responsible for the crop. If the purchaser does not accept the stock under these terms, they are to be returned at once and the money will be refunded.

However, it must be plain to anyone of intelligence that I will do my best to send out only such stock as will grow and prove true to description. It certainly is to my best interests to do this-and I will.

Visitors Always Welcome. I extend a cordial invitation to my customers to visit my place.

\section{W. E. K ING \\ Little Silver, NEW JERSEY}




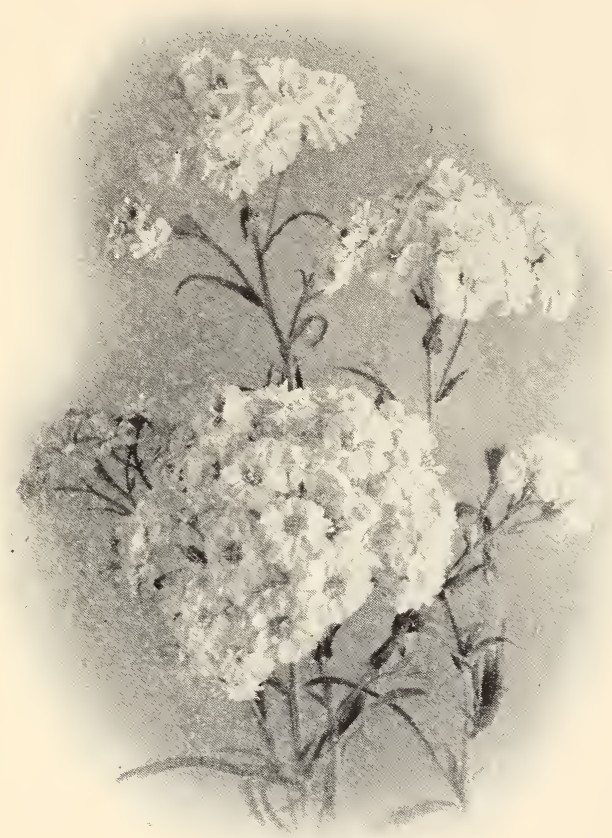

Achillea Ptarmica, "The Pearl"

\section{Achillea}

Millefolium roseum. A handsome variety of this class, with rose-colored flowers in great profusion all summer.

Ptarmica, "The Pearl." Pure white flowers, on strong stems 2 feet high blooming profusely. Fine for cutting; very showy.

Either variety, $15 \mathrm{cts}$. each, $\$ 1.50$ per doz.; larger size, 25 cts. each, $\$ 2.50$ per doz.

\section{Alyssum (Basket of Gold)}

Saxatile compactum. A splendid plant for borders and rockery, growing about I foot high, with masses of bright yellow flowers, and beautiful foliage. I 5 cts. each, \$I.5O per doz.

\section{Anchusa}

Italica. Grows 3 to 4 feet; very effective in hardy border or planted among shrubs. Flowers blue, in June; strong grower. I5 cts. each, \$I.5O per doz.; large plants, $25 \mathrm{cts}$. each, $\$ 2.5^{\circ}$ per doz.

Dropmore. A big improvement over the Italica. The color is rich gentian-blue, a color of which we have too little. Planted with larkspurs the effect is grand, as they form big plants 4 to 5 feet high, with numerous branches. 25 cts. each, \$2.50 per doz. 


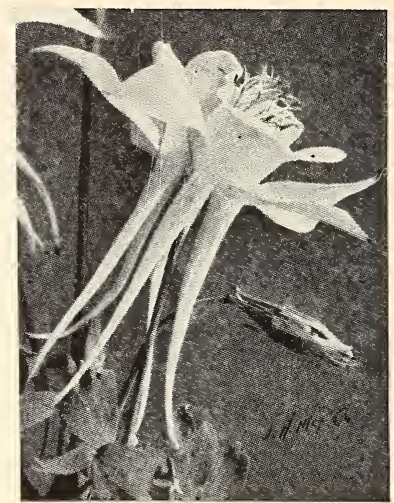

Aquilegia

\section{Aquilegia}

Columbine

California Hybrids. A splendid mixture, bea t if ul colors. Bloom in early summer months, on slender stems. I $5 \mathrm{c}$. each, $\$$ I.50 per doz.; large plants, 25 cts. each, $\$ 2.50$ per doz.

\section{Bocconia}

Plume Poppy

Cordata Japonica. Strong grower, 6 to 8 feet, adapted for planting in shrubbery borders; ornamental foliage with cream-colored flowers borne in large, showy panicles. I $5 \mathrm{cts}$. each, $\$ \mathrm{I} .50$ per doz.; large plants, $25 \mathrm{cts}$. each, $\$ 2.50$ per doz.

\section{Campanula}

Medium (Canterbury Bells). An old favorite, also known as Cup-and-Saucer flowers. Height 3 feet. stalks should be tied to stakes to produce straight stems. Colors, Blue, Pink and White. I2 cts. each, $\$ \mathrm{I} .25$ per doz.

Pyramidalis (Chimney Bellflower). The most conspicuous of the Campanulas, forming a perfect pyramid 4 to 6 feet high, crowded with blue flowers in August. 25 cts. each, $\$ 2.50$ per doz.

\section{Hardy Chrysanthemums}

Large flowers; every garden should have this collection. All strong plants that will bloom the first season. Order by name. Cerise Queen, pink; Daybreak, soft pink; Golden Pheasant, yellow; Julia Lagravere, garnet; King Philip, rose-pink; Prince of Wales, white; St. Almo, pure white; Sunset, rich yellow. 10 cts. each, $\$ 1$ per doz.

Check inclosed for $\$ 2$, for which please send Hardy Chrysanthemums. We bought some Hollyhock plants from you last fall and they are the envy of the neighbors.-R. L. BARTLETT, May I3, I9I5.

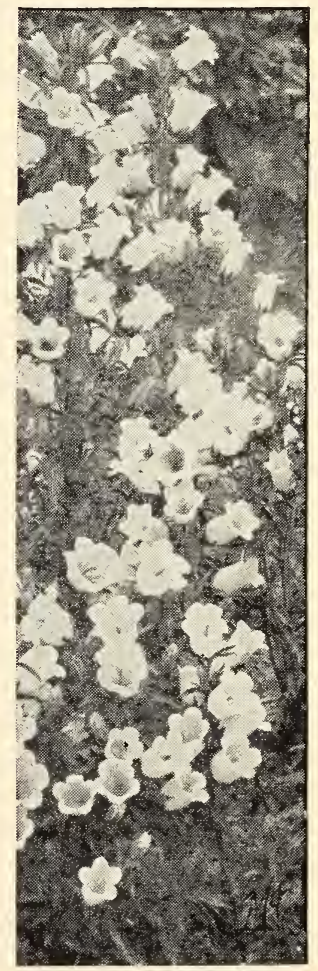

Campanula Medium 
HARDY CHRYSANTHEMUMS, continued

King Edward. Pure white flowers; an improved form of Shasta Daisy. 20 cts. each, \$2 per doz.

Shasta Daisy. Too well known to need description. Strong plants, I5 cts. each, $\$ \mathrm{I} .50$ per doz.

\section{Coreopsis}

Lanceolata grandiflora. Very popular; fine for cutting; blooms all summer in masses of golden yellow flowers; height 2 to 3 feet. Succeeds everywhere. 12 cts. each, $\$ 1.25$ per doz.; large plants, 25 cts. each, $\$ 2.50$ per doz.

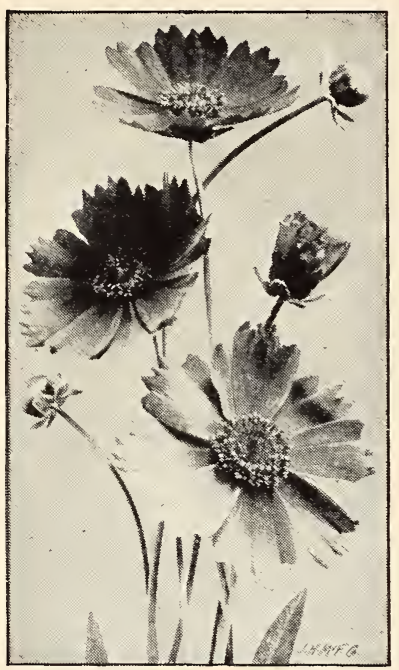

Coreopsis

\section{Delphinium (Hardy Larkspur)}

Belladonna. The best of all the Hardy Larkspurs; flowers turquoise-blue, in bloom from June until frost cuts them down. Height 2 to 3 feet. $25 \mathrm{cts}$. each, $\$ 2.5^{\circ}$ per doz.

Chinese. Pretty dwarf variety, with feathery foliage and deep blue flowers in open panicles. I5 cts. each, \$I.5O per doz.

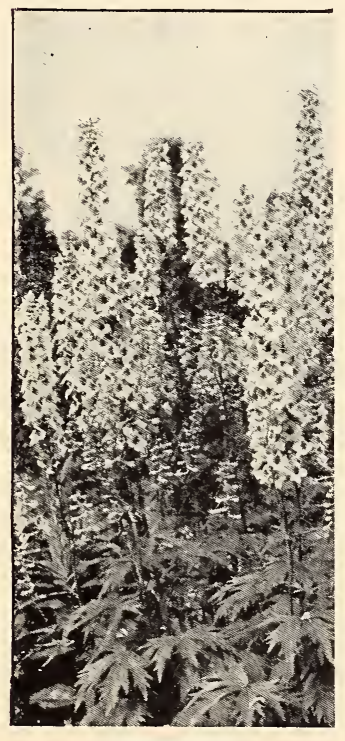

Delphiniums

Formosum. The old favorite Larkspur our grandmothers grew; grows about 3 feet high; dark blue flowers with white center; free bloomer; one of the best. I $5 \mathrm{cts}$. each, \$I.5O per doz.

\section{Dianthus}

\section{Hardy Pinks}

Clove-scented. The old favorite; blooms all summer; mixed colors.

Latifolius. Beautiful summer bedding plant; produces masses of fiery crimson flowers throughout the summer.

Barbatus. See Sweet William.

Both varieties, $10 \mathrm{cts}$. each, $\$ 1$ per doz.

Please send one dozen Hardy Larkspurs. The plants you sent before arrived in good condition and all are growing well.-J. C. Miller, July 8, I9I5. 


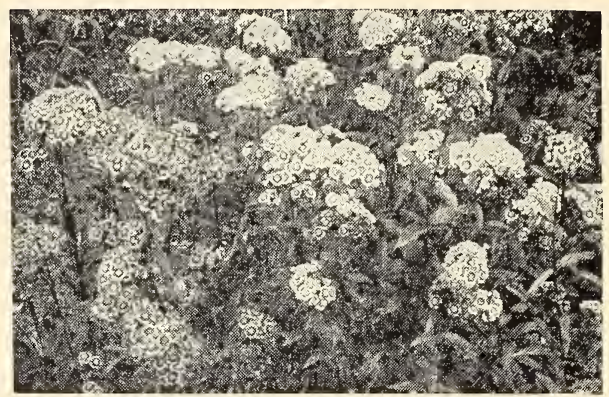

Sweet William (Dianthus barbatus). See page I4

\section{Digitalis (Foxglove)}

Gloxiniæflora. No hardy garden is complete without the beautiful Foxgloves. I can offer these in four colors-White, Pink, Lilac and Purple; also mixed. I 2 cts. each, \$I.25 per doz.

\section{Funkia (Plantain Lily)}

Variegata. Variegated foliage, green and white; purple flowers. Useful for edging; very effective; blooms in July; height 2 feet. I 5 cts. each, \$I.5O per doz.

\section{Gaillardia (Blanket Flower)}

Grandiflora. One of the best for the hardy border; showy; constant display of flowers from June until frost. Colors are gorgeous and in endless variety of

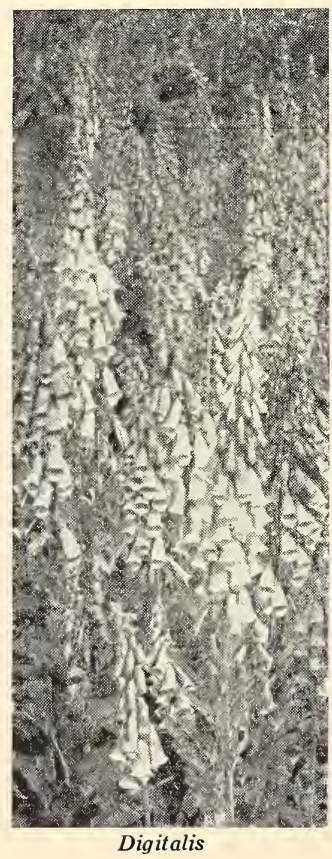
orange, red, brilliant crimson, dark brown and vermilion. I $2 \mathrm{c}$. ea., \$I.25 per doz.; large plants, 25 c. each, $\$ 2.50$ per doz.

\section{Grasses}

\section{Hardy Ornamental}

These grasses are very effective when planted among shrubbery, or planted as single plants on the lawn; soon grow into beautiful specimens and take care of themselves. I offer four varieties:

Eulalia gracillima. Of graceful habit with narrow foliage of bright green, with a silvery midrib.

Eulalia Japonica. Very ornamental; bright green.

The plants sent before continue to do well, especially the Veronicas which are very fine. I hope you will be able to supply me with equally good Phlox and Anemones for I am greatly pleased with them.Mrs. E. B. Hill, June I3, 'I5. 
GRASSES, cóntinued

Eulalia Japonica variegata. Similar to the preceding, but is striped with light yellow, giving the whole plant a most beautiful effect.

Eulalia Japonica zebrina. The long blades of this variety are marked with bands of yellow across the leaves. Makes an attractive specimen for the lawn. All these Eulalias grow about 5 feet high and are perfectly hardy.

Strong plants, 25 cts. each; clumps, 50 cts. each

\section{Gypsophila (Baby's Breath)}

Paniculata. One of the most graceful of the hardy plants. Blooms during August and September; forms a symmetrical mass 2 to 3 feet high, of bush form; beautiful white flowers, producing a gauze-like appearance; fine for cutting. I 2 cts. each, \$I.25 per doz.

\section{Hemerocallis (Yellow Day Lily)}

Flava. The best-known variety of Hemerocallis. Deep lemon-yellow flowers in June and July; very fragrant; height $21 / 2$ feet. I5 cts. each, \$I.5O per doz.; large plants, 25 cts. each, $\$ 2.5^{\circ}$ per doz.

\section{Helianthus (Hardy Sunflower)}

Maximiliana. One of the best of the Hardy Sunflowers, with golden yellow flowers in long, graceful sprays during the early fall months; invaluable for cutting; height 5 to 7 feet. I 5 cts. each, \$I.50 per doz.; large plants, 25 cts. each, $\$ 2.50$ per doz.

\section{Heliopsis (Orange Sunflower)}

Pitcheriana. Flowers are 2 inches in diameter; deep golden yellow; flower early in season and continue all summer. Very useful for cutting; height 3 feet. I 5 cts. each, \$I.50 per doz.

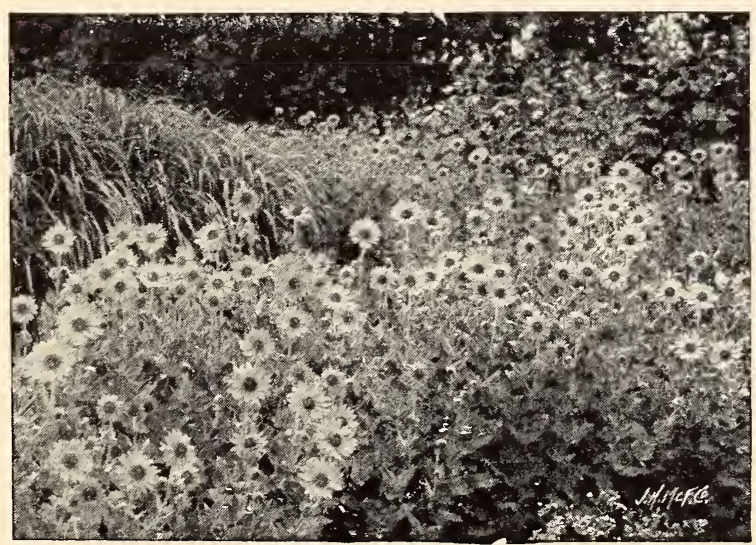

Hardy Sunflowers 


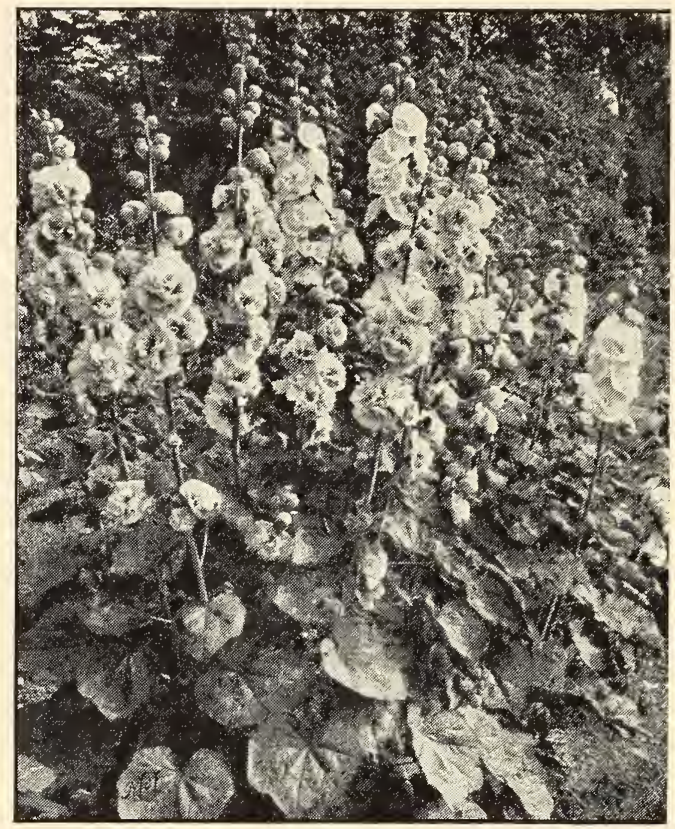

Hollyhocks

\section{Hesperis (Rocket)}

Matronalis. Pink flowers on bushy plants; stronggrowing; very showy; height 3 to 4 feet. Blooms in June and July. Io cts. each, \$I per doz.

\section{King's Superb Hollyhocks}

The stock I offer this season is unusually fine, and will give an abundance of bloom next year. Hollyhocks are at their best when planted in clumps on the lawn, or as a part of the background to the hardy border. They are also very useful in hiding a fence or yard or some spot that is undesirable. I offer separate colors in

\section{Double White Double Salmon \\ Double Rose Double Maroon \\ Double Yellow Double Red}

15 cts. each, $\$ 1.50$ per doz., $\$ 10$ per 100 ; extra-large, 2year-old plants, 25 cts. each, $\$ 2.50$ per doz.

Double Mixed. All the above colors, but in taking the seed it has been mixed, so I cannot sell in colors. Io cts. each, \$I per doz., \$7.50 per ioo; extra-large, 2-year-old plants, $20 \mathrm{cts}$. each, $\$ 2$ per doz.

All the plants came to hand in good condition. Please accept thanks for the extras.-S. M. MAckenzie, May I 2, I9I 5 .

The I oo hardy plants ordered on the 9 th, and received on the IIth, were all in fine, fresh condition, showing both skill and intelligence in packing. Thank you for promptness and careful attention to my order.-GEo. M. PotTER, June I7, I9I5. 


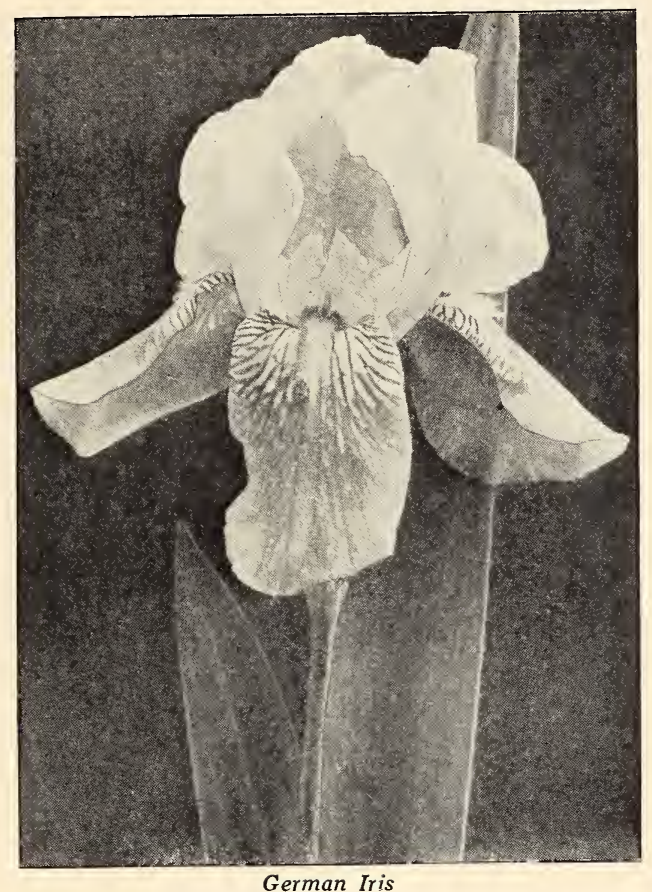

\section{German Iris (Iris Germanica)}

The German Irises are among the most popular of the spring-flowering hardy plants, producing in May their showy flowers of beautiful coloring. These Irises resemble the beautiful orchids; in fact the marvelous veining and tracing and the delicate intermingling of colors give them a charm which no other flower possesses; many have a delicious fragrance. My collection is not extensive, but each variety is distinctly different in color and form.

Celeste. Pure celestial blue; beautiful flower; tall and majestic; fine for massing.

Darius. Bright yellow, lower petals veined purple and rosy lilac; dwarf in habit.

Delicata. Pale yellow, lower petals rosy purple; very large flower.

H. Cramer. Delicate lavender, lower petals a shade darker. One of the finest and most showy.

Madame Chereau. Pearly white, distinctly and daintily edged and penciled with violet; rather dwarf. One of the most beautiful.

Pallida Dalmatica. One of the finest of the Germanica type. Strong, vigorous habit; planted in good soil will attain 4 feet in height, with unusually large flowers of a most beautiful shade of lavender; very fragrant. Large plants, 75 cts. each, $\$ 7.50$ per doz.; small plants (regular commercial size), 25 cts. each, $\$ 2.50$ per doz.

Purple Queen. One of the earliest; large flowers of rich violet-purple, on tall stems. 
GERMAN IRIS, continued

Honorabilis. Golden yellow, lower petals rich mahogany; flowers held high above the foliage; one of the best of the yellows.

Any of the Iris, except where noted, large plants (fully three times the size of the small plants), 25 cts. each, $\$ 2.50$ per doz.; small plants (regular commercial size), $10 \mathrm{cts}$. each, $\$ 1$ per doz.

\section{Lathyrus (Hardy Sweet Pea)}

Latifolius. Flowers are pea-like; a strong, climbing plant valuable for covering trellises. Blooms summer and autumn; colors rosy pink and white. I5 cts. each, \$I.50 per doz.

\section{Lupinus (Lupine)}

Polyphyllus. Clear blue flowers on large spikes; height about 3 feet; blooms in May and June.

Polyphyllus albus. A white variety of the above.

Polyphyllus roseus. A pink variety, similar to the above.

$25 \mathrm{cts}$. each, $\$ 2.50$ per doz.

\section{Lychnis (Campion)}

Chalcedonica. Most desirable plant, with heads of orange-scarlet flowers and dark green foliage. A fine old garden flower; very showy and nice for cutting. 12 cts. each, \$I.25 per doz.

\section{Monarda (Bergamot)}

Didyma rosea. Showy plants that produce rosecolored flowers all summer, with aromatic foliage; succeed well anywhere. I5 cts. each, \$I.50 per doz.

\section{Myosotis (Forget-me-not)}

Palustris semperflorens. The best variety; hardly ever out of bloom; useful for shady spot in border. Io cts. each, \$I per doz.

\section{Papaver (Poppy)}

Orientalis (Oriental Poppy). A most pleasing plant of easy culture. Produces large flowers, often 5 to 7 inches across. Colors range from pink to dark crimson, each with a large spot of glossy black in the center; height 2 to 3 feet. I $5 \mathrm{cts}$. each, \$I.50 per doz.

\section{Pentstemon}

Barbatus Torreyi. Spikes of brilliant scarlet flowers, growing 3 to 4 feet high, June to August.

Digitalis. Large spikes of long, purple-white flowers during June and July. 2 to 3 feet.

Pubescens. Bright rosy purple; July and August; height 18 inches.

Any of the above, $15 \mathrm{cts}$. each, $\$ 1.50$ per doz. 


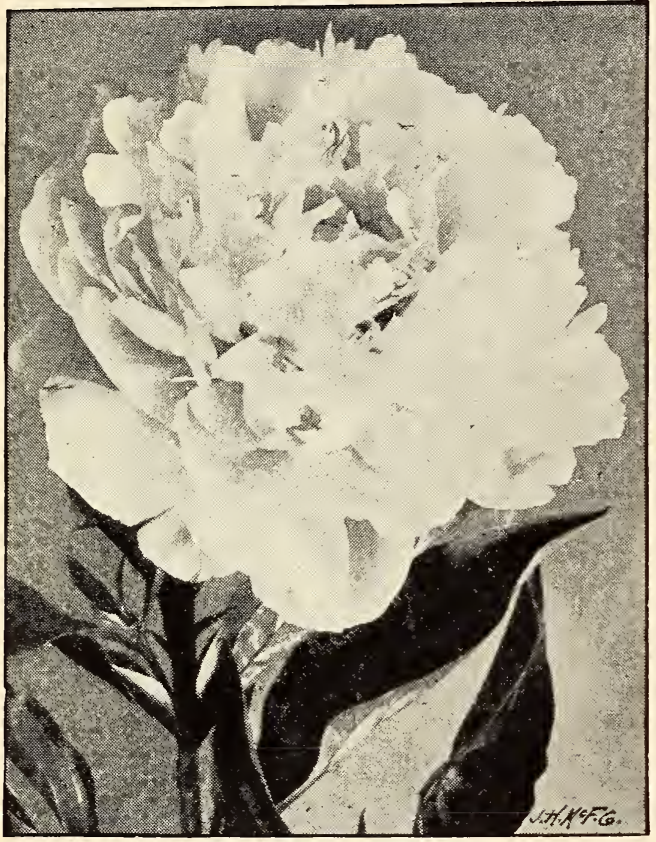

Festiva Maxima Peony

\section{Double Herbaceous Peonies}

The Peony is called the "Queen of the Spring" and certainly is in a class by itself. The best effect to be had with these plants is in masses or beds; they are also popular plants for the hardy border.

\section{NAMED VARIETIES}

Delicatissima. Rose; large flower.

Humei. Soft pink.

Mars. Deep crimson.

Queen Victoria. White with crimson center.

Festiva Maxima. Great, large blooms, white with splashes of crimson in the center.

Any variety, 25 cts. each, $\$ 2.50$ per doz.; large plants, 75 cts. each, $\$ 7.50$ per doz.

\section{UNNAMED VARIETIES}

In separate colors, Red, Pink and White, 20 cts. each, $\$ 2$ per doz.; large plants, 50 cts. each, \$5 per doz.

\section{Potentilla}

Mixed colors only. Flowers are produced in profusion from June to August. A good plant for the border; height I 8 inches. I 5 cts. each, $\$$ I.5O per doz.

\section{Physostegia (False Dragonhead)}

Virginica. Beautiful, midsummer flowering perennial; the flowers resemble large heather; color shell-pink. On strong stems, excellent for cutting. I 2 cts. each, $\$ 1.25$ per doz.; large plants, $25 \mathrm{cts}$. each, \$2.50 per doz. 


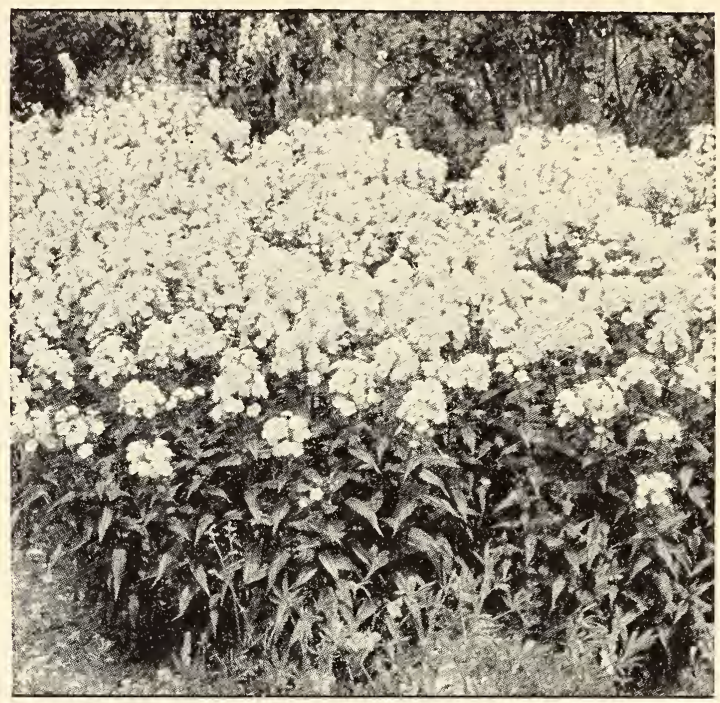

\section{King's Extra-Fine Hardy Phloxes}

Probably no other plant in the hardy "old-fashioned" flowers gives more real satisfaction than the Phlox. By planting in masses the effect is wonderful, and in the border, or a mong shrubbery, the sight is very pleasing. Of the many hundreds of varieties, I offer those that I believe are the best, the most distinct and free from disease.

\section{Beautiful Phloxes of Recent Introduction}

Astrild. Brilliant carmine-red; flowers of medium size, rich and attractive.

B. Comte. Brilliant rich purple; very showy and a fine flower. Considered one of the best in the purples.

Elizabeth Campbell. Bright salmon-pink, with red eye. One of the handsomest and attracts more attention than any other Phlox. No collection is complete without this.

Europa. Very large flowers and truss; color white with crimson eye. Very new and the best in its class.

Frau Anton Buchner. Pure white flowers, the largest truss and individual flower of the white Phlox; rather dwarf; a fine variety for border of bed of Phloxes.

Rheinlander. Beautiful salmon-pink, with red eye; the trusses are of immense size.

Tragedie. A brilliant, rich, deep carmine, with bloodred eye. One of the richest colors.

Wanadis. A mottling of white and light violet; each flower has a distinct reddish eye; very showy.

W. C. Egan. One of the finest Phloxes yet introduced. The color is a light lilac, illuminated by a large, bright solferino eye; the color effect, as a whole, is a pleasing shade of soft pink. 
PHLOXES OF RECENT INTRODUCTION, continued

Widar. Reddish violet, with large white center, which intensifies and illuminates the color.

Von Lassburg. One of the best whites; flower and truss are of immense size; dwarf, branching habit.

Siebold. One of the best scarlets; large flowers. No collection is complete without this fine red.

Any of the foregoing varieties, $30 \mathrm{cts}$. each, $\$ 3$ per doz. One each of the 12 varieties for $\$ 2.50$

\section{King's Superb Hardy Phlox}

This is the general collection of Phloxes that have been known for several years; varieties that have proved to be the best in their class, each distinct from the other.

Bouquet Fleuri. White, with light carmine eye, the color when planted in mass is pure white; showy and of dwarf habit.

Bridesmaid. Pure white, with large red eye; large flower and truss; good variety to plant with pure white and scarlet, or in fact with any color.

Coquelicot. A fine, pure scarlet, with large truss; the color is really orange-scarlet; it is entirely unlike any other shade of color in Phloxes.

Eclaireur. Bright purple, with lighter halo; quite distinct from anything else in this class.

E. Danzanvillier. Lilac, shading to white at the edges; very attractive and a decorative color.

Joan of Arc. The best late white, and for that reason should be in every collection; fine for massing.

Miss Lingard (Phlox suffruticosa). Early blooming. This Phlox begins to bloom six weeks earlier than any other and continues to bloom during the whole summer. The color is pure white, with lilac eye; very large individual florets. One of the finest of all Phloxes. 20 cts. each, \$2 per doz.

Mme. P. Langier. Bright crimson, good color, does not fade; strong and vigorous.

Mrs. Jenkins. A splendid white; immense clusters of flowers; early and free bloomer.

Pantheon. A good pink; very showy and attractive.

R. P. Struthers. Rosy carmine, with red eye; early and free bloomer; one of the best in this shade of red.

Sunshine. Aniline-red, with crimson eye; showy.

Schlieman. Bright pink, with red eye; tall and a good bloomer.

Any of the above, except where noted, $15 \mathrm{cts}$. each, $\$ 1.50$ per doz. One each of the 13 varieties for $\$ 1.50$. One each of the 25 varieties for $\$ 3.75$.

\section{Rudbeckia (Giant Purple Coneflower)}

Purpurea. Flowers 3 to 4 inches across, of a peculiar reddish purple, with large, cone-shaped center of brown; bushy plants, 3 feet high; blooms from July to October. I 5 cts. each, $\$$ I.50 per doz.

Golden Glow. A well-known popular plant. A strong, robust grower; produces masses of double, golden yellow cactus-dahlia-like flowers on tall stems, 5 feet high, July to September. I2 cts. each, \$I.25 per doz. 


\section{Salvia (Hardy Sage)}

Azurea grandiflora. Blooms during August and September, bearing sky-blue flowers on stems 3 feet high, in the greatest profusion. I5 cts. each, $\$$ I.50 per doz.

\section{Stokesia (Cornflower Aster)}

Cyanea. Beautiful plant, grows 18 to 24 inches high; flowers freely from June to September, bearing handsome, lavender-blue cornflower-like blossoms. Useful for cutting. No collection is complete without these grand plants. I 2 cts. each, \$I.25 per doz.

\section{Sweet William (Dianthus barbatus)}

A great improvement has been made in this favorite flower of our grandmothers, the flowers being larger and the colors more brilliant. Strong field plants in pure white, mixed colors and the new variety, Newport Pink. Io cts. each, \$I per doz.

\section{Valeriana (Garden Heliotrope)}

Coccinea. Showy heads of red flowers; blooms all summer.

Coccinea alba. A white form of the above.

Officinalis. Bright pink flowers, from June to August, with strong heliotrope odor.

All varieties, $15 \mathrm{cts}$. each, $\$ 1.50$ per doz.; large plants, 25 cts. each, $\$ 2.50$ per doz.

\section{Veronica (Speedwell)}

Longifolia subsessilis. The best of all the hardy Veronicas, and beyond question the best perennial giving blue flowers. Blooms from early summer until frost, producing tall spikes that almost cover the plant. I5 cts. each, \$I.5O per doz.; large plants, 25 cts. each, $\$ 2.50$ per doz.; very large clumps, four years old, \$I each.

Spicata. An elegant border plant, growing about 18 inches high, producing long spikes of bright blue flowers in June and July. An extremely desirable border plant. I $5 \mathrm{cts}$. each, $\$ \mathrm{I} .5^{\circ}$ per doz.

\section{Wallflower}

The old favorite Wallflowers; mixed colors, including yellow, brown, etc. Blooms profusely, with flowers in spikes. I5 cts. each, $\$$ I.5O per doz.

\section{Yucca (Adam's Needle)}

Filamentosa. This plant stands at the head of hardy ornamental foliage and flowering plants. Has broad, sword-like foliage and grows 5 to 6 feet tall, with branched spikes of large, fragrant, drooping, creamy white flowers during June and July. A very effective plant for all positions. The foliage is evergreen. 25 cts. each, $\$ 2.5^{\circ}$ per doz. 


\section{ORDER BLANK. \\ W. E. KING, LITTLE SILVER, N. J. Florist-Hardy . Old-Fashioned Flowers.}

Date.

Name

Post Office

St. or R. F. D.

Express Office.

Am't Enclosed

\begin{tabular}{|c|c|c|c|}
\hline Quantity. & Names of Plants Wanted. & Dollars. & Cents. \\
\hline & & & \\
\hline & & & \\
\hline & & & \\
\hline & & & \\
\hline & & & \\
\hline & & & \\
\hline & & & \\
\hline & . & & \\
\hline & & & \\
\hline & & & \\
\hline & & te & \\
\hline & & & \\
\hline & & & \\
\hline & & & \\
\hline
\end{tabular}






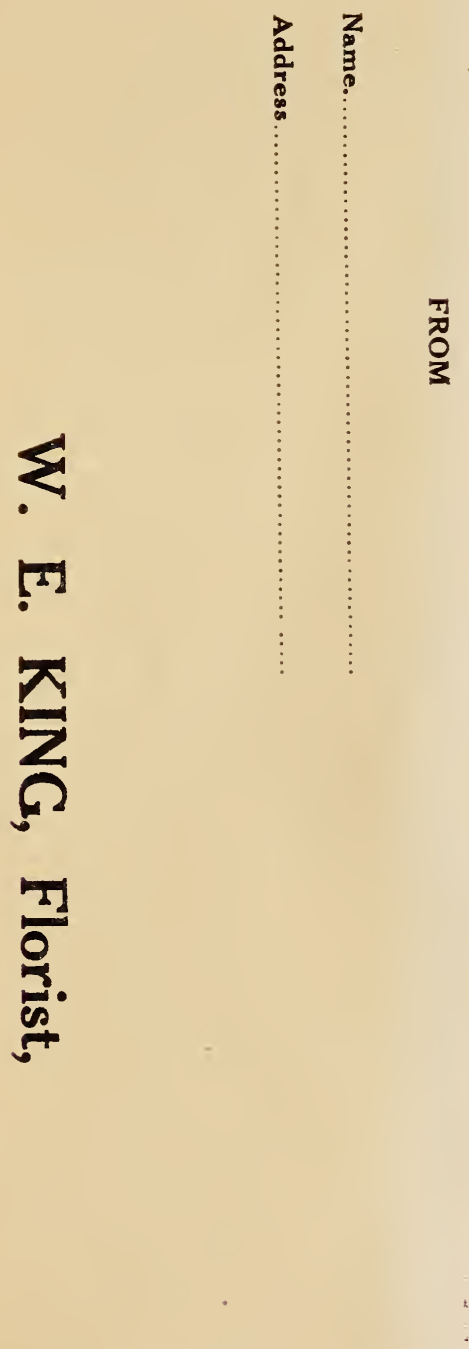





\section{LARGE PLANTS FOR}

\section{IMMEDIATE EFFECT}

Last spring I introduced the idea of planting large plants, 2 or 3 times the size of the regular commercial-size plant, and it met with success and so much appreciation that this fall I have added several more varieties; these are mentioned as "Large Size."

For instance: In the Iris Germanica I offer the "Large Size;" these plants are 3 times the size of the regular size offered at \$I per dozen, and instead of one eye or division you will have three or more; this will naturally give you three times as many flowers the first year. For quick results buy the "Large-Size" plants. They will please you.

The plants came Friday in excellent condition. I am much pleased with the collection, to which, later, it is my intention to add. I would appreciate your guidance in making an old-fashioned garden in September when we return from California.Mrs. T. G. Bergen, July i9, I9I5.

I received my flowers today in most excellent condition. Thanks for the present of the Daisy.MrS. W. S. FrENCH, June I I, I9I 5. 


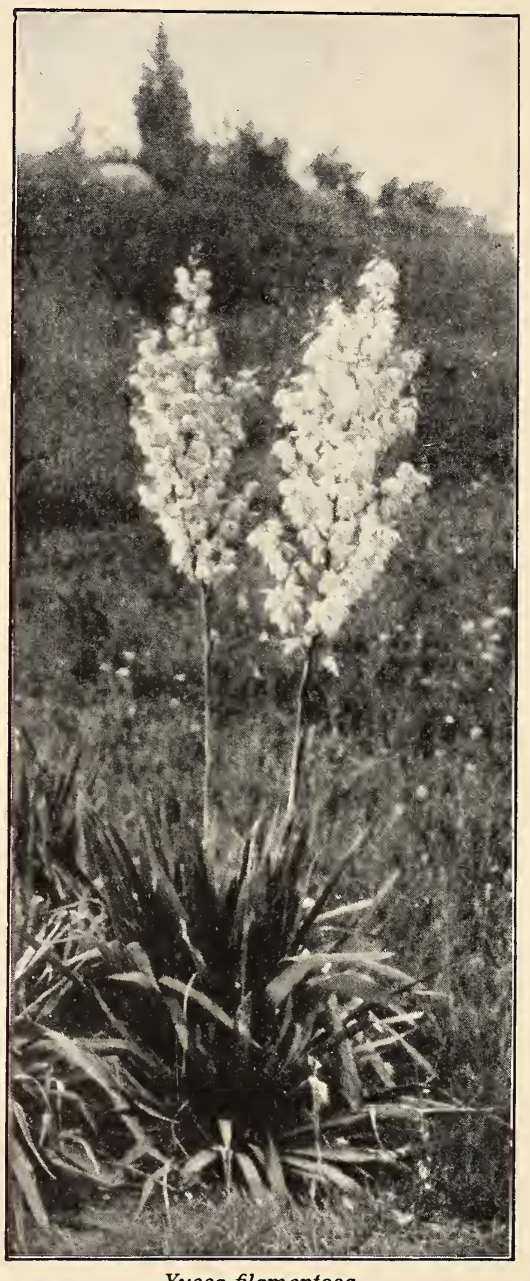

Yucca filamentosa

See page I4

\section{W. E. KING}

LITTLE SILVER, NEW JERSEY 